\title{
Media and Communication Strategies Supporting Parents and Children in COVID-19 Pandemic Environment
}

\author{
Mihaela Racheva \\ Sofia University "ST. Kliment Ohridski” \\ Медии и комуникативни стратегии, подпомагащи родители и деца в \\ условията на пандемията COVID-19
}

Михаела Рачева

Софийски университет „Св. Климент Охридски”

\begin{abstract}
Author note
Mihaela Racheva (iD) https://orcid.org/0000-0002-5552-2346
\end{abstract}

The author has no conflict of interest for disclosure.

Correspondence related to this article should be addressed to Sofia University, Faculty of Medicine, Lozenets Base, Mihaela Racheva, Sofia. Str. Shipchenski prohod 69A Email: mracheva1@abv.bg

\section{Бележки за автора}

Михаела Рачева (D) https://orcid.org/0000-0002-5552-2346

Авторът няма конфликт на интереси.

Кореспонденцията, свързана с тази статия, да се адресира до Михаела Рачева, Софийски университет „Св.Св. Климент Охридски, Медицински факултет, София, ул. Шипченски проход 69 А. Email: mracheva1@abv.bg 
Abstract
The article addresses the social and emotional problems of children and students during the
isolation that transformed the lives of children, parents, and society. Emphasis is placed on the
need to support parents and train them in skills that will be useful in the fight against childhood
obesity in Bulgaria (based on media and communication strategies) in the context of the COVID-19.

Keywords: media and communication strategies, parents, children, COVID-19, childhood obesity in Bulgaria

\section{Резюме}

Статията засяга социалните и емоционалните проблеми на децата и учениците по време на изолацията трансформирала живота на деца, родители и общество. Акцентира се върху необходимостта от подпомагане на родителите и тяхното обучение на умения, които да са в полза относно борбата със затлъстяването на децата в България (базирано на медийни и комуникационни стратегии) в условията на пандемията COVID-19.

Ключови думи: медийни и комуникационни стратегии, родители, деца, COVID-19, затлъстяването на децата в България

ARTICLE INFO: 


\section{Медии и комуникативни стратегии, подпомагащи родители и деца в условията на пандемията COVID-19}

Целта на статията и предложената и изпълнявана от нас изследователска програма бе повишаване на обществената чувствителност и създаване на условия за широка публична медийна кампания, относно необходимостта от борба със затлъстяването в България в условията на пандемията COVID-19. Програмата е от изключително важно значение за съвременното общество, тъй като засягания от нас въпрос е глобален. В подкрепа на този извод е статистиката, извеждаща посочения проблем като ключов за Европа, а по отношение на неговото решаване България заема незавидно място.

Начинът на хранене играе роля при терапията на затлъстяване при деца, и ето защо, за нас е много важно ДА ОБУЧИМ РОДИТЕЛИТЕ, които да бъдат естествен регулатор в семейната структура, особено сега, когато в условията на пандемията COVID-19 децата са твърде обездвижени. Нужно е да се знае, че превенцията е много по-успешна и допринася за по-добър контрол с цел здравословен начин на живот. Обсъждането на негативните аспекти - депресивна симптоматика, нереалистични очаквания, трудности с приспособяване към новата социална роля, подготвя и информира респондентите - деца и възрастни с наднормено тегло и затлъстяване. В този смисъл обучението и медиите изпълняват важна превантивна роля, тъй като начинът на хранене е определящ в рамките на поставените цели в настоящия проект. Целта ни бе да въведем корекция в стила на живот на затлъстелите и да предприемем превантивни действия за развитие на редица хронични заболявания, както и да осьществим превенция на децата в семейна структура с родител с наднормено тегло и/или хронично заболяване, поради рисковия фактор от генетична обремененост в условията на пандемията COVID-19. Считаме, че широка публична медийна кампания ще спомогне за преодоляването на този проблем. Възпитанието в семейството от ранна възраст на здравословен стил на живот е ключов в превенцията на затлъстяването. Този извод се налага най-малко поради обстоятелството, че според изследвания, извършвани във страни със сериозен принос в борбата с наднорменото тегло, като Франция, например - при всеки 2 от 10 деца се наблюдава патология свързана със затлъстяването. И ако за тях не се положат грижи, пак - според същото изследване - изводите сочат, че $80 \%$ ще имат сериозно проблеми с теглото в зряла възраст. За съжаление подобни тревожни са и данните за България. Към момента статистическите данни по въпроса са твърде противоречиви и оспорвани, но според последните валидни резултати - от 2006г. на International Association for the Study of Obesity - 15,3\% от мъжете и 20,9\% от жените имат сериозни проблеми с теглото. При 
децата този процент е 12.5 \%. През 2012 г. Българското дружество по ендокринология провежда епидемиологично обследване за разпространението на затлъстяването с цел актуализация на данните. Данните са още по-тревожни, като се има предвид, че сега в България лицата със затльстяване са 33,2\% от населението. (Racheva, 2019)

Ползването на медиите винаги включва разнообразие от възможности за избор, които подобряват или влошават нашия живот. Ето защо реципиентите се информират и се учат кои фактори влияят върху избора им на точно определен продукт, кои фактори въздействат върху техните деца да желаят точно определена стока. Има много начини една стока да бъде направена привлекателна - рекламата ни кара да мислим, че трябва да купим точно този продукт, но от друга страна рекламата често дава доста неясна информация, особено когато става дума за нездравословни храни. Това сега в условията на пандемията COVID-19 е твърде актуално, защото медиите имат първостепенно значение при комуникацията между реципиентите - деца и възрастни. Реципиентите се информират и за други похвати, които изкушават децата да желаят определени стоки и нездравословни храни в условията на пандемията COVID-19:

1. Интернет - сайтове за деца и подрастващи имат линкове към сайтове за нездравословна храна

2. Анимационните герои - ако децата харесват дадения герой напълно сигурно е, че ще поискат продукта с героите на опаковката.

3. Известните личности и звезди - спортистите, които рекламират газирани напитки и/или нездравословна храна води до сериозно противоречие в детското съзнание перфектно тяло, добра визия и в същото време консумират вредни продукти.

4. Подарък играчка - избора на детско меню в редица вериги за бързо хранене, заради играчката, а не заради самата храна.

Известно е, че човек от раждането си до края на ранното детство складира в паметта си информация, която може да обуслови неговото хранително поведение. Ето защо по време на обучението, децата ще са обучавани стьпка по стъпка на факторите, които водят до прибягването към храна, не само за задоволяване на физиологичната ни потребност, а до т.нар. „емоционално хранене”, което крие редица рискове за нашето здраве. Запознават се с най-ранния етап от човешкото развитие - неправилното възприемане на емоциите на кърмачето от неговите родители или от непосредственото му обкръжение, което може да доведе до създаване на лошо отношение към храната. Това е и причината да се научим да разкодираме детския плач. Той може да означава глад, но също така и болка, страх, желание за ласки. Ако в тези случаи системно даваме 
храна на детето, рискът от объркване ще доведе до нарушения в пораждането на емоциите му, които недиференцирано ще бъдат компенсирани чрез приемане на храна „емоционално хранене”. Изследването ни се опира на различни формати, имащи за цел усъвършенстване на обучителната програма:

- Схема-терапия (разширена когнитивна-поведенческа терапия по Джефри Янг) Теоретичен модул с водещ д-р Алп Караосманоглу, психиатър и Директор на центьр за психотерапия и обучение в Истанбул, София 2019.

- Участие в 9-ия Световен Конгрес по Поведенческа терапия, юли 2019, Берлин.

- Участие в сертифициран уъркшоп на тема „Когнитивно-поведенчески подход за отслабване и запазване на теглото“ с водещ д-р Джудит Бек, Президент на Института Бек, юни 2019.

В периода 10 - 13.10.2019 взехме участие в Национален симпозиум по ендокринология - на тема „Диабет - нов подход в лечението” и представих работата ми във връзка с пациентите - деца и възрастни в екипа на болница „Софиямед” под ръководството на проф. Анна-Мария Борисова - началник клиника и председател на Българско дружество по ендокринология.

В периода от 05.07.2019 до 22.12.2019 продължи работата ни в клиника по Ендокринология към болница „Софиямед” по програма - обучение на пациенти - деца и възрастни с наднормено тегло и затлъстяване. За този период сме изследвали още 98 пациента. Всички 265 лица, които изследвахме, имаха възможност да попълнят/или да им се попълнят(при децата, които не пишат) предварително изготвени анкетни карти, които целят да оценят нагласата към здравословен начин на живот, информираност по отношение на здравословно хранене и тенденция към емоционално хранене. Предварителните резултати показват, че при по-малко от $10 \%$ от изследваните се наблюдава контрол на храненето, което още веднъж свидетелства за необходимостта от усвояване на умението човек да бъде по-отговорен към собственото си поведение. Анкетите съдържат лична информация и 21 айтема. Предстои обработка на данните от проучването ни. По тази част от изследователската ни програма бяха проведени обучения под формата на лекционен курс (72 часа) с теория и практическа част, групова и индивидуална психотерапия в Университетска болница „Софиямед” под ръководството на проф. Анна-Мария Борисова-началник клиника по „Ендокринология и болести на обмяната на веществата”, за пациенти с наднормено тегло и затлъстяване. Във връзка с пандемията от COVID-19 уточнихме и последващата ни програма за действие. 
1. Продължаване на работата по образователната кампания с пациенти - деца и възрастни с наднормено тегло, затлъстяване и хронични заболявания.

2. Изпълняване на програмата по отношение на медийното послание. В нея се обръща внимание на медийното въздействие върху пациентите - деца и възрастни в условията на пандемията COVID-19.

3. Разработване на медийна кампания, която включва разработването на редица материали (брошури, постери, рубрики във вестници, в тази връзка са ни предоставени авторските права за книгата на Linda W. Graighead, PhD, professor of psychology at Emory University in Atlanta and director of the graduate training program in clinical psychology - “Training Your Inner Pup to Eat Well”).

4. Създаване на собствен сайт и разработването на материали за него, отделни специализирани рубрики, които и да повишат информираността на пациентите - деца и възрастни в условията на пандемията COVID-19.

От тази гледна точка работната ни програма се свежда до:

1. Прилагане на съвременните технологии в ежедневието - стремеж към един поздравословен начин на живот;

2. Използване на приложения и видео игри насърчаващи към физическа активност;

3. Ограмотяване в различните хранителни групи;

4. Приложения имащи антистрес ефект;

5. Водене на хранителен дневник и дневник на автоматичните мисли.

6. Психообучение за изграждането на умения за активно слушане, емпатийно отношение, автентично поведение - ключови елементи в общуването между родители и деца.

Това последното е от особена важност в условията на пандемията COVID-19. Ето защо със сигурност не малка част от децата (дори и тези, които пристъпват прага на училище) са доста по-напред от родителите си (да не говорим за родителите на техните родители) в способностите си да търсят, намират, генерират и променят медийни съобщения. Така емпатията много зависи от нашата настройка към собствените ни емоции, чрез които рефлективно се отразяват чуждите емоции. При раждането си децата не притежават култура и концепция за света. Те ги придобиват като извличат знания и опит от различни източници - както социални, така и несоциални. Пьрвите си познания за света детето получава в семейството. От общуването с възрастните, възприемайки част от техните морални стойности и като подражава на моделите им на поведение, то постепенно оформя своята ценностна система и светоглед. За развитието на 
подрастващите са особено важни първите години. Тогава те са „бял лист” с голям капацитет, върху който всичко написано остава. В тази възраст децата имат голяма нужда от задоволяване на емоционалните си нужди, за да се развиват правилно. В ранния период от своето развитие те трябва да получават позитивни усещания, интелектуални стимули, забавления и удоволствия, които да се превърнат в ценна мотивация за овладяване на определени норми и начини на поведение, което предопределя емпатията. И ако в съвременното общество всичко това детето добива главно от външни източници, то във времето преди „Гутенберговата епоха“ семейството и училището са основните места, от които детето задоволява своите емоционални и духовни потребности. Но в необятното интернет пространство потребителите, и най-вече децата вече търсят не само информация. Там те създават общества, в които контактуват помежду си без родителска намеса (Angelova, \& Angelov, 2020). Възможностите за съвместни занимания в мрежа, за влизане в уеб сайтове стимулира от една страна емоционалното израстване на децата, а от друга има и силно социализираща функция. Не са за пренебрегване и чат - сесиите (в последните години най-силно проявени чрез мобилните устройства), в които децата контактуват писмено на специфичен език (Angelov, \& Danov, 2020). Анонимността на мрежата дава възможност без страх от критики да се споделят лични проблеми, да се търси (и намира) тяхното “разрешение”, да се създават контакти с други хора и т.н. Бързото откриване на информация в избрано от потребителя (детето) време е също предпоставка много хора да се обърнат към компютъра и таблета, вместо към телевизора. Децата - потребители са по-активни от децата - зрители. Влизайки в интернет, те не просто наблюдават случващото се на монитора, а имат активна роля в подбора на това, което искат да четат, гледат, слушат. Възможността за концентрация върху дадена тема тук е много по-голяма, отколкото при непрекъснатото превключване на телевизионните канали. Интернет в някаква степен връща и боравенето с писменото слово, тъй като по-голяма част от информацията в него е в писмен вид. Телевизията, колкото и модерни форми да търси за разнообразяване на програмата си, не може да се съревновава с това, което Интернет предлага на децата.И тук във връзка с емпатията трябва преди всичко да потърсим много точното съотношение между дейност и самосъзнание, използвайки като модел психологията на детската игра и ролите, които детето поема в нея. “Социалната роля” сякаш свързва дейността на личността и нейното самосъзнание с функционирането на социалната система. Следователно личността не може да определи себе си независимо от системата на своите “социални роли”, тя може да се слива, да се идентифицира с тях или да се отделя, да се дистанцира от тях, но във 
всички случаи при определянето на своето “аз” те сякаш служат за личността като отправна точка.Тук виждаме връзка и с психодраматичният ролеви тренинг, който е базиран на психодраматичната ролева теория. Не може да се отрече, че в живота на децата емоционалните реакции играят значителна роля, защото те са първата форма на връзка на детето с обкръжаващата го среда. Те са значими и поради това, че служат за отчитане на отношението му към предметния свят и представляват едно от средствата за общуване с възрастните и връстниците. Не е необходимо детето да остава безучастен съзерцател на събитията от медиите. То активно трябва да преживява ситуациите, в които попадат любимите му герои. Получава се едно противоречие. В случая силната емоция на децата е необходима, желана и води до емпатия. И родители и възпитатели трябва да търсят връзката между рационално и емоционално в преживяванията на децата пред телевизионния екран, за да не станат в живота нечувствителни към страданията на другите. Ето защо афишираното по-горе психообучение в условията на пандемията COVID-19 е изключително важно за изграждането на умения за активно слушане, емпатийно отношение, автентично поведение - ключови елементи в общуването между родители и деца чрез широка публична медийна кампания.

\section{Използвана литература:}

Angelova, L., \& Angelov, B. (2020). Medii, obrazovanie, sotsialno obshtuvane [Media, education, social communication] Obrazovanie i tekhnologii [Education and Technologies], 11(1). http://doi.org/10.26883/2010.201.2167

Angelov, B., \& Danov, D. (2020). Komunikativna kompetentnost-ezikovi i mediĭni izmereniya [Communicative competence - linguistic and media dimensions]. In B.Angelov, \& D. Danov (Eds), (2020) Teoretichni aspekti i prilozhni izsledvaniya v oblastta na mediunata pedagogika [Theoretical aspects and applied research in the field of media pedagogy] (pp.27) SU "St. Kliment Ohridski".

Racheva, M. (2019). Mediĭna gramotnost i kognitivno povedencheska terapiya [Media literacy and cognitive behavioral therapy]. In B. Angelov (ed), Sŭvremenni tendentsii $\mathrm{v}$ preduchilishtnoto vŭzpitanie [Contemporary trends in preschool education] (pp.8498). ISSN $2367-5284$ 